\title{
Population connectivity of Ezo abalone on the northern Pacific coast of Japan in relation to the establishment of harvest refugia
}

\author{
Yoichi Miyake ${ }^{1,3, *}$, Shingo Kimura ${ }^{1}$, Tomohiko Kawamura ${ }^{1}$, Takashi Kitagawa ${ }^{1}$, \\ Tetsuya Takahashi ${ }^{1}$, Hideki Takami ${ }^{2}$
}

\author{
${ }^{1}$ Atmosphere and Ocean Research Institute, The University of Tokyo, Kashiwa, Chiba 277-8564, Japan \\ ${ }^{2}$ Tohoku National Fisheries Research Institute, Fisheries Research Agency, Shinhama, Shiogama, Miyagi 985-0001, Japan \\ ${ }^{3}$ Present address: Graduate School of Fisheries Science and Environmental Studies, Nagasaki University, Bunkyo-machi, \\ Nagasaki 852-8521, Japan
}

\begin{abstract}
Population connectivity among 7 fishery grounds of Ezo abalone Haliotis discus hannai on the northern Miyagi coast (approximately $80 \mathrm{~km}$ ) was investigated using hydrodynamic and particle-tracking models. The objectives were to: (1) clarify the larval dispersal processes, (2) quantify the dispersal distance of larvae and (3) estimate the population connectivity. To simulate larval dispersal, particles were released at the timings of spawning estimated from the shell lengths of newly settled abalone. The larval dispersal was simulated for 2 periods. The modeled hydrodynamics in the first period simulated stormy conditions because of the passage of a lowpressure system whereas that in the second period simulated relatively calm conditions. In the first period, the spawning appeared to be triggered by the low-pressure system, and the larval dispersal was estimated to be generally greater than that in the second period. The mean dispersal distances were less than $40 \mathrm{~km}$ in both periods. Model results indicate that abalone in the fishery grounds on the mid- and southern coast exhibit 2 distinct larval dispersal patterns. The number of connected sites was 3 to 7 and 2 to 4 in the stormy and relatively calm conditions, respectively. The calmer hydrodynamic conditions were favorable for self-replenishment. Self-recruitment was usually greater than the connectivity with the other fishery grounds; however, poor self-recruitment occurred in some fishery grounds. This implies that the restocking and protection of local resources do not always lead to an increase in local recruitment, and it is necessary to investigate the larval dispersal processes from each larval source for successful management.
\end{abstract}

KEY WORDS: Connectivity - Larval dispersal - Harvest refugia - Marine reserve Abalone · Haliotis discus hannai $\cdot$ Numerical modeling

\section{INTRODUCTION}

Many groups of marine species disperse during their planktonic larval period. Larval dispersal is the mechanism for establishing population connectivity of benthic species with pelagic larval stages, e.g. clams (Hinata \& Furukawa 2006) and corals (Underwood et al. 2007). Population connectivity is defined as the exchange of individuals among disjunct subpopulations (a group of individuals interacting with each other in the same habitat patch), and comprises the dispersal stage between reproduction and recruitment for benthic-oriented species (Cowen \& Sponaugle 2009). Connectivity can play a significant role in the persistence of the local populations and stocks for heavily exploited species. Furthermore, 
connectivity is one of the elements that impact the success of restocking (Lipcius et al. 2008). Therefore, an understanding of the larval dispersal and population connectivity is crucial for successful fisheries resource management.

Ezo abalone Haliotis discus hannai inhabit the northern Pacific coast of Honshu Island and the western coast of Hokkaido Island, Japan, and are one of the most important fishery resources. H. discus hannai are mainly distributed in the areas of high algal production in the sublittoral zone up to $10 \mathrm{~m}$ deep (Sasaki 2005). The distribution of this abalone species ranges from exposed coasts facing the open ocean to bays on the Miyagi coast located northeast of Honshu Island, but they are more abundant on the exposed coasts with high availability of food (e.g. Eisenia bicylis, Gelidium spp., and Acrosorium spp.), gentle bottom incline and many undulations (Sasaki 2001). The catch of this species started to decline in the early 1970s, and the hatchery-reared abalone have been released into the fishery grounds since the late 1970s. The catch started to increase in 1997; however, it still remains one-third of the level prior to the decline. Abalone species are dioecious broadcast spawners, and have planktonic larval stages before transitioning into crawling benthic stages (Kawamura et al. 2002). The catch could have risen if the majority of restocked populations contributed to the enhancement of metapopulations through connectivity. The current restocking may not have taken place at effective locations for self-recruitment and larval supply to or from other subpopulations. Therefore, restoration measures that can facilitate the population connectivity are needed.

Sasaki \& Shepherd (1995) found that epidemic spawning of Haliotis discus hannai on the Miyagi coast is induced by typhoons and minor storms, and larval dispersal over long distances (i.e. up to $3 \mathrm{~km}$ ) occurs after typhoons whereas larvae are locally dispersed after minor storms. The larval dispersal duration of $H$. discus hannai in the natural environment has been estimated to be limited ( 4 to 6 d; Takami et al. 2006), although under experimental condition, it was found to be extended if the larvae did not contact an appropriate stimulus for metamorphosis into crawling postlarvae (Takami et al. 2002). Studies on their larval dispersal processes can provide valuable information for planning fishery management and restoration of the species. However, there is a difficulty in clarifying these processes solely by field surveys because of this species' potentially wide larval dispersal (scale of kilometers) and short planktonic stages.
Marine reserves can result in increased stock of exploited species (Durán \& Castilla 1989, Babcock et al. 1999, Kelly et al. 2000, Russ \& Alcala 2003, Cudney-Bueno et al. 2009). However, the effectiveness of marine reserves can vary depending on the species (Dufour et al. 1995) and locations (Cudney-Bueno et al. 2009). The reserves that are managed to improve fisheries by providing adults and propagules through dispersal are often termed 'harvest refugia' (Allison et al. 1998). For the efficient management of abalone fisheries, the effectiveness of harvest refugia needs to be evaluated, specifically for the target species and location.

Particle-tracking models have been applied to investigate the larval dispersal of benthic organisms such as clams (Hinata \& Furukawa 2006), oysters (North et al. 2008), lobsters (Lipcius et al. 2001) and abalone (McShane et al. 1988, Stephens et al. 2006, Piggott et al. 2008, Miyake et al. 2009, 2010, Watson et al. 2010). Because of the difficulties in elucidating larval dispersal processes of Haliotis discus hannai by the distribution of larvae, further investigations employing numerical simulations are necessary to grasp the complete picture. The results that are obtained through the numerical simulations allow us to investigate the effectiveness of reserves (Lipcius et al. 2001, Miyake et al. 2009, 2010). Both timing of the spawning and larval duration can have a strong influence on the connectivity of coastal species (e.g. Watson et al. 2010). In the present study, these factors were therefore taken into account, and the temporally and spatially varying flow field was generated within a nested area, coupled with the reanalysis data from JCOPE2 (Miyazawa et al. 2009), for subsequent larval dispersal simulations. Using the results of larval dispersal simulations, we investigated the population connectivity among fishery grounds on the northern Pacific coast of Japan to estimate effective locations for various types of harvest refugia, which would facilitate the improvement of the current fishery management by restocking. In the present study, a group of individuals in a fishery ground was assumed to be a subpopulation.

Our study objectives were to: (1) clarify the larval dispersal processes, (2) quantify the dispersal distance of larvae and (3) estimate the population connectivity among 7 fishery grounds of Haliotis discus hannai on the northern Pacific coast of Japan. For the future fisheries management of abalone species, a case study in this area could provide useful information on larval dispersal processes and establishment of harvest refugia on the coast facing the open ocean. 


\section{MATERIALS AND METHODS}

\section{Study area}

The study area was located off the coast of Miyagi Prefecture (Fig. 1), situated on the northeastern coast of Honshu Island, Japan. The northern part of the study area is characterized by a sawtooth coastline (approximately $80 \mathrm{~km}$ ) consisting of a series of bays and headlands, and Sendai Bay covers most of the southern part of the study area. The study area is under the influence of the water masses from the Oyashio, Tsugaru Warm Current, and Kuroshio (Hanawa \& Mitsudera 1987). In the coastal areas, the Tsugaru Warm Current water dominates with frequent Kuroshio water appearances in summer and fall whereas the Oyashio water dominates in winter and spring in the upper layer (Hanawa \& Mitsudera 1987). The approach of cold water from the Oyashio to the coastal areas in winter has been suggested to result in high mortality of young-of-the-year abalone (Takami et al. 2008).

\section{Hydrodynamic model}

To simulate the hydrodynamic conditions in the study area during the spawning season in 2006, Delft3D-FLOW (WL I Delft Hydraulics) was used. The

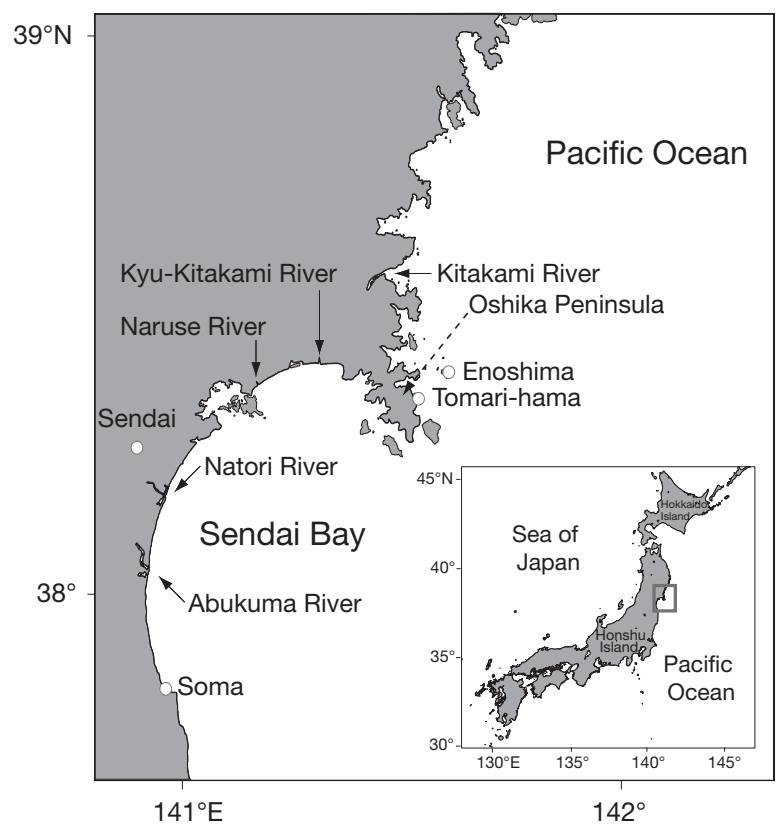

Fig. 1. The Miyagi coast, with locations of river mouths (solid arrows), the Oshika Peninsula (dashed arrow) and climatological and oceanographic measurement stations (O). Inset: the location of the Miyagi coast in Japan model domain consisted of a $1 \times 1 \mathrm{~km}$ regular grid in a horizontal direction with $20 \sigma$-grid layers, in which the thickness of a layer was $5 \%$ of the depth, in a vertical direction. The model domain extended $124 \mathrm{~km}$ longitudinally and $152 \mathrm{~km}$ latitudinally. The model bathymetry was created from $500 \mathrm{~m}$ mesh depth data (Japan Oceanographic Data Center). The daily average reanalysis data (flows, salinity and temperature) from JCOPE2 (Miyazawa et al. 2009) were used for the initial and boundary conditions. The boundary conditions of the model were daily varying current velocities (north-south component) at the north and south boundaries, and hourly tidal height at the east boundary. The tidal height was calculated using NAO.99Jb (Matsumoto et al. 2000). Time series data of daily salinity and temperature from JCOPE2 were prescribed at all boundaries.

The freshwater discharge was prescribed at the mouths of rivers (Fig. 2) using river flux data (Japan

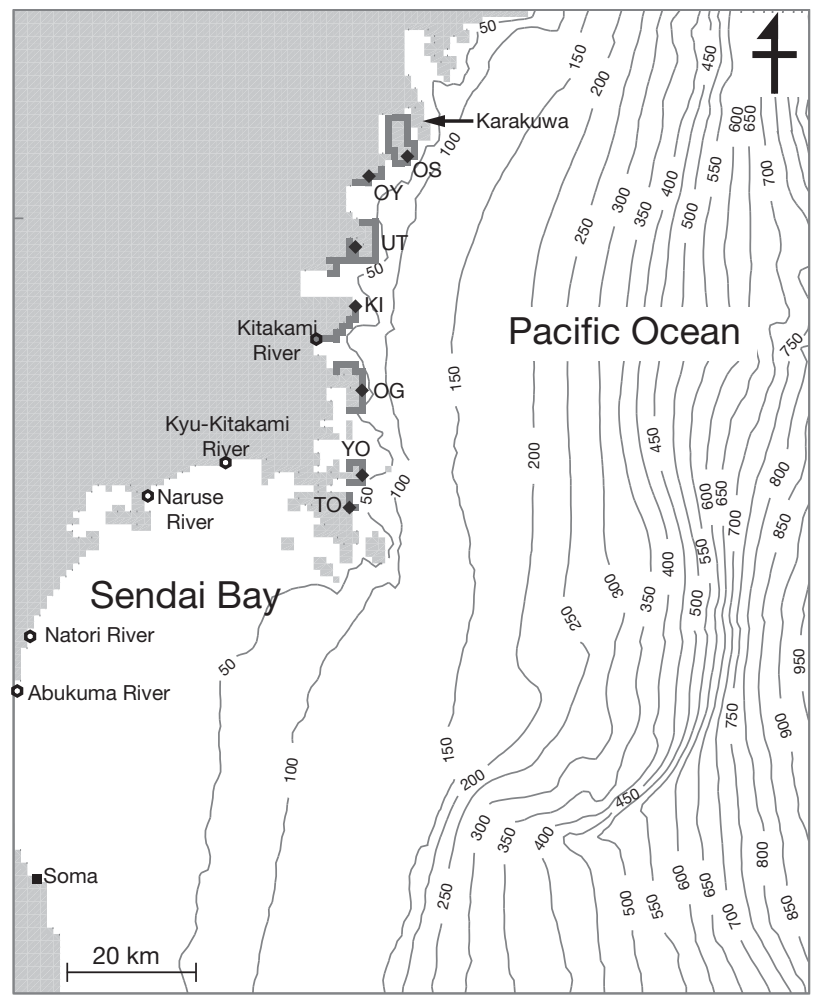

Fig. 2. Modeled area, showing locations of particle release sites and freshwater discharge sites. Isobaths are in meters. The black diamonds indicate the single grid cells where 1000 particles were released to estimate larval dispersal processes and distances. The particle release sites for estimating connectivity are shaded dark gray. The freshwater discharge sites are indicated by black hexagons, and the sea level measurement site (Soma) is indicated by a black square. The diamond at TO also indicates the bottom water temperature measurement site (Tomari-hama). See 'Materials and methods - particle-tracking model' for abbreviations of release sites 
River Association) and water temperature data (Water Information System, Ministry of Land, Infrastructure and Transport, Japan). Daily mean flux data from 1994 to 2003 were averaged for each month (August to November). Missing water temperature data were linearly interpolated using previous and subsequent available data.

The surface was forced with temporally and spatially varying wind and atmospheric pressure at the sea level. Climatological data (wind, atmospheric pressure, temperature and relative humidity) with a spatial resolution of $10 \times 10 \mathrm{~km}$ and a temporal resolution of $3 \mathrm{~h}$ from MANAL (Meso-scale analysis data, Japan Meteorological Agency) were used. The MANAL data that were closest to each grid cell of the hydrodynamic model were used.

The heat exchange through the surface was calculated by using a heat flux model in which the relative humidity, air temperature, and fraction of cloud coverage were prescribed. The relative humidity and air temperature data from MANAL were spatially averaged at available times. The fraction cloud coverage data were obtained from the Japan Meteorological Agency. The background horizontal eddy viscosity and diffusivity were set to $10 \mathrm{~m}^{2} \mathrm{~s}^{-1}$. The viscosity and diffusivity, in addition to the background values, were calculated with the Horizontal Large Eddy Simulation (Delft Hydraulics 2008). The background vertical eddy viscosity and diffusivity were set to $10^{-4} \mathrm{~m}^{2} \mathrm{~s}^{-1}$. The additional viscosity and diffusivity were computed with the $k-\varepsilon$ turbulence model. The time step was set to $60 \mathrm{~s}$. Secchi depth was set to $11 \mathrm{~m}$ because it has been reported to be between 7 and $15 \mathrm{~m}$ in the Oyashio area (Saijo \& Ichimura 1960). The Dalton number was set to $1.2 \times 10^{3}$, which is calibrated for Japanese waters (Delft Hydraulics 2008), and the Stanton number was set to 1.2.

The hydrodynamic model was run with forcing conditions from August to September to spin up the model in preparation for the later period (October to early November). The results of the hydrodynamic model from 1 October to 3 November (including the larval dispersal simulation period, discussed in 'Results - modeled hydrodynamics') were compared between the observed and modeled sea level variations (i.e. difference between the sea level and its mean) at Soma and bottom water temperature variations at Tomari-hama (Figs. 1 \& 2), using the model skill score and root mean square error (RMSE). The perfect agreement of observed and modeled data yields a model skill score of one, whereas complete disagreement yields the score of zero (Warner et al. 2005). The observed data for sea level and bottom water temperature were obtained from the Geographical Survey Institute and the Tohoku National Fisheries Research Institute, respectively. The periods with missing observed data were excluded from the comparison. The observed and modeled variations agreed well. The RMSEs for sea level and bottom water temperature were $0.17 \mathrm{~m}$ and $0.44^{\circ} \mathrm{C}$, respectively. The model skill scores for sea level and bottom water temperature were 0.94 and 0.95 , respectively.

\section{Particle-tracking model}

Delft-PART was used for simulating the larval dispersal of Haliotis discus hannai. PART computes the position of every individual particle by advection and dispersion, and simulates transport processes by means of a particle-tracking method using flow data from FLOW (Delft Hydraulics 2007). Passive particles were used to simulate larvae. The larval dispersal simulations included neither larval behavior nor mortality because: (1) field estimates of mortality are unavailable and (2) the study species inhabits rocky shores and spawns during stormy ocean conditions or when wave heights are relatively greater. Thus, it is likely that vertical behavior of larvae is overwhelmed by turbulent mixing. The horizontal dispersion coefficient was set to the same value as the background horizontal dispersal coefficient in the hydrodynamic model, and the vertical dispersion coefficient was calculated by the 'depth-averaged algebraic', which assumes the vertical dispersion to be constant over depth but to vary with locations due to varying depths (Delft Hydraulics 2007). Time steps for the particle-tracking calculation were set to $60 \mathrm{~s}$.

Seven fishery grounds were chosen as the particle release sites. Two particle release sites, Oshima (OS; Fig. 2) and Tomari-hama (TO), were the sites where earlier studies on Haliotis discus hannai had been carried out (Sasaki \& Shepherd 1995, Sasaki \& Shepherd 2001). The remaining 5 release sites were Ohya (OY; Fig. 2), Utatsu (UT), Kitakami (KI), Ogatsu-tobu (OG) and Yoriiso (YO), where the catch of abalone was high (>15 t) in 2006 (Statistics Department, Tohoku Regional Agricultural Administration Office 2008). Although the catch in Karakuwa was 24 t, this fishery ground was not included in the simulations because it was close to the northern boundary of the model domain and another particle release site (OS). The time of particle release was determined by estimating the spawning date (see 'Estimation of settlement and spawning dates' below). Because $H$. discus hannai spawn during dark periods (Sasaki 2001), 
particles were released at 00:00 $\mathrm{h}$ on the estimated spawning date and the following $2 \mathrm{~d}$. Particles were evenly spread and released in the range of $500 \mathrm{~m}$ from the center. The dispersal distances of particles were measured from the center of particle release. The competent period for settlement (hereafter referred to as the competent period) was assumed to be 4 to $6 \mathrm{~d}$ after the particle release because the age of newly metamorphosed postlarvae had been estimated to be 4 to $6 \mathrm{~d}$ old in this area (Takami et al. 2006). The particles that reached the grid cells next to the land (the area up to between 1 and $1.4 \mathrm{~km}$ offshore) during the competent period were stopped, and they were considered settled. Two types of particle-tracking simulations were carried out. First, 1000 particles were released at the bottom layer in one grid cell in each particle release site to quantify the dispersal distance from the fishery grounds. Second, multiple grid cells that can cover the entire area of each fishery ground (but strictly next to the land) were chosen for the particle release (>880 particles) to estimate the connectivity among the fishery grounds. Connectivity was defined as the percent of particles that returned to the fishery ground of origin or reached the other fishery grounds during the competent period per number of released particles. Selfrecruitment was defined as the connectivity with the fishery ground of origin. Transport success was calculated for a fishery ground where particles were released, and was defined as the percentage of particles that settled in any of the 7 fishery grounds per number of released particles. Recruitment score was defined as the total connectivity for a fishery ground, which was calculated for the particles released at all sites but settled in the subject fishery ground. Connectivity and other related values were calculated on the assumption that the numbers of larvae from all fishery grounds were equal.

\section{Estimation of settlement and spawning dates}

For estimation of settlement and spawning dates of Haliotis discus hannai in 2006, the shell lengths (SLs) of newly settled abalone on the boulders collected at 3 randomly chosen sites off Tomari-hama on 13 and 20 October and 10 November were used. After immersion in a $5 \%(\mathrm{v} / \mathrm{v})$ solution of ethanol in seawater, the boulders were gently brushed with a soft brush to collect the attached individuals. The SLs of the collected individuals were measured to the nearest $0.1 \mathrm{~mm}$ in the laboratory using a video camera system with an image analyzer connected to a dissecting mi- croscope. The settlement dates were back-calculated using the larval size and growth rate of newly settled abalone, and then spawning dates were estimated using the back-calculated settlement dates and the length of the larval stage. The settlement date $\left(D_{1}\right)$ and spawning date $\left(D_{0}\right)$ were estimated as:

$$
\begin{gathered}
D_{1}=D_{2}-\left(L_{\mathrm{t}}-L_{\mathrm{l}}\right) / G \\
D_{0}=D_{1}-t_{1}
\end{gathered}
$$

where $G$ is the growth rate $\left(40 \mu \mathrm{m} \mathrm{d}^{-1}\right.$; Takami et al. 2008), $L_{\mathrm{l}}$ is the larval size $\left(276.5 \mu \mathrm{m}_{i}\right.$ Hayashi 1983$), L_{\mathrm{t}}$ is the SL of newly settled abalone, $D_{2}$ is the sampling date and $t_{1}$ is the length of the larval stage (4 to $6 \mathrm{~d}$; Takami et al. 2006). Sasaki (2001) reported that large- and small-scale spawning events of $H$. discus hannai off the coast of Miyagi Prefecture were associated with maximum significant wave heights $>4 \mathrm{~m}$ and in a range of 2 to $4 \mathrm{~m}$, respectively. Thus, the estimated spawning dates were compared with the atmospheric pressure at sea level at Sendai and maximum significant wave height at Enoshima (Fig. 1) from July to November. These environmental data were obtained from the Japan Meteorological Agency. Although the estimated dates were calculated based on the SLs of newly settled abalone collected off Tomari-hama, it was assumed that spawning occurred concurrently at all fishery grounds.

\section{RESULTS}

\section{Modeled hydrodynamics}

Modeled hydrodynamics in 2 simulation periods, 4 to 12 October and 26 October to 3 November, are shown in Figs. 3 and 4, respectively. In the first simulation period (Fig. 3), the dominant flow direction along the coast was south from 4 to 7 October. The flows were intensified on 6 October and became stronger the next day because of the passage of a low-pressure system along the Pacific coast of Honshu Island (see Fig. 5 for the decline in the atmospheric pressure). A large clockwise eddy formed near the northern coastal area on 8 October. This eddy propagated southward, and the dominant direction of the coastal flow near the western side of this eddy was northward. The first simulation period can be characterized by stormy hydrodynamic conditions, which showed strong southward flows and the subsequent eddy formation causing northward coastal currents. In the second simulation period, the hydrodynamic conditions were relatively calmer compared with that in the first period (Fig. 4). During the second 

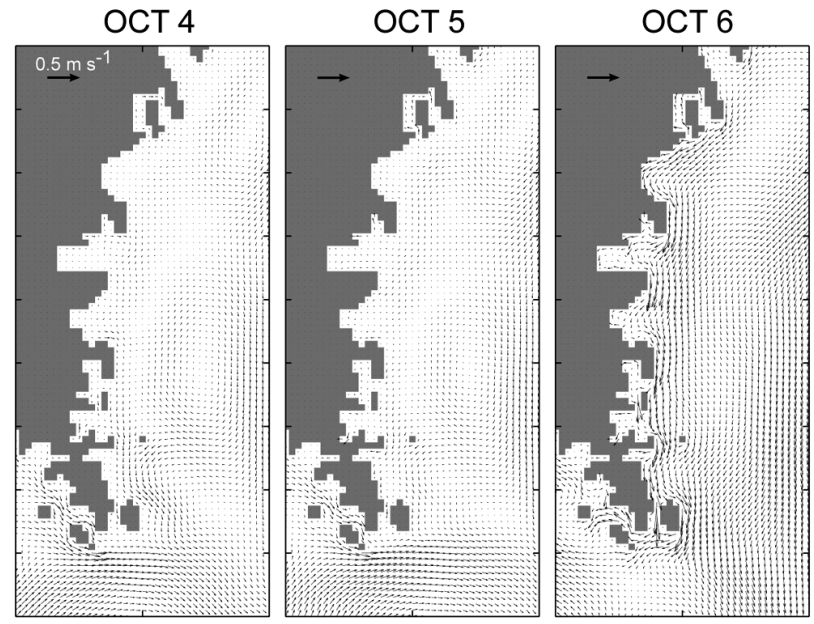

OCT 7
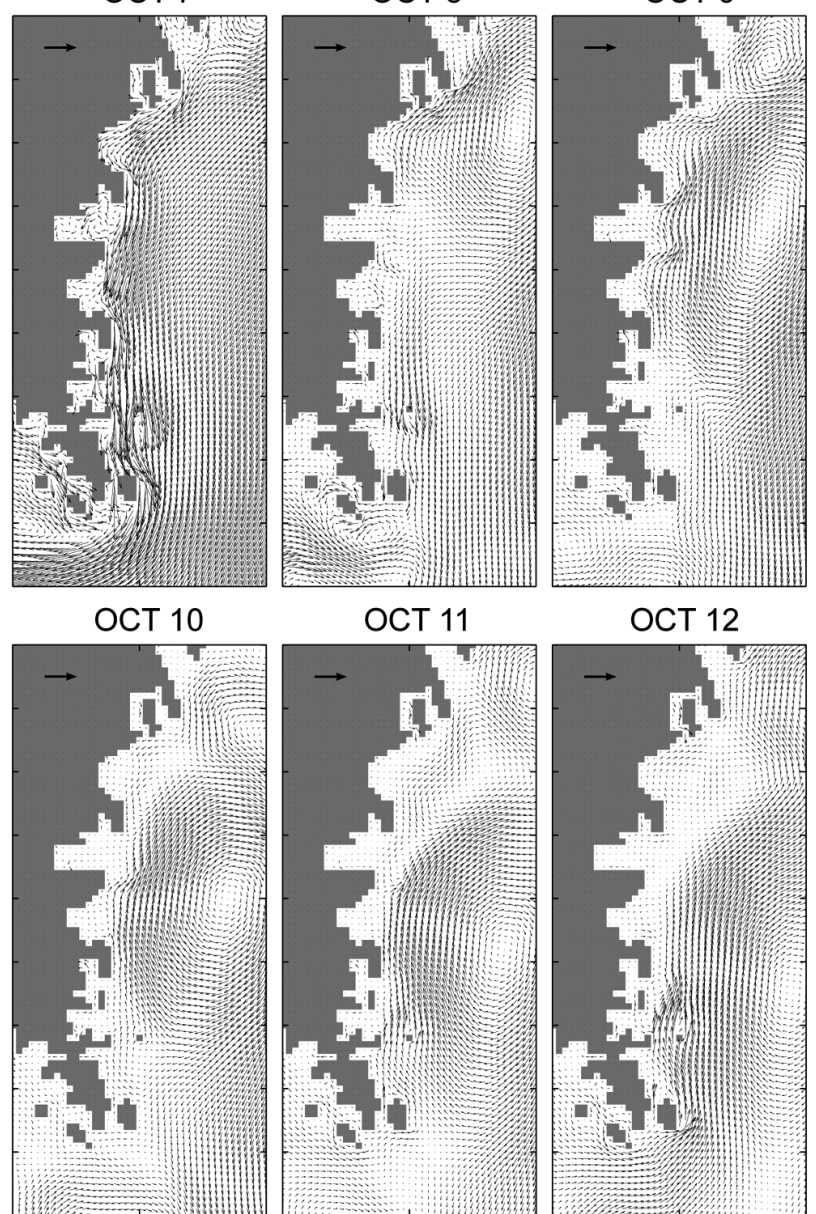

Fig. 3. Modeled hydrodynamics along the coast during the first simulation period (4-12 October 2006). Arrows indicate the magnitude and directions of vertically averaged flow. Panels show daily hydrodynamic fields at 00:00 h

period, the dominant direction of coastal flow was northward. Thus, the second simulation can be characterized by the calmer hydrodynamic conditions with relatively weak northward coastal currents.
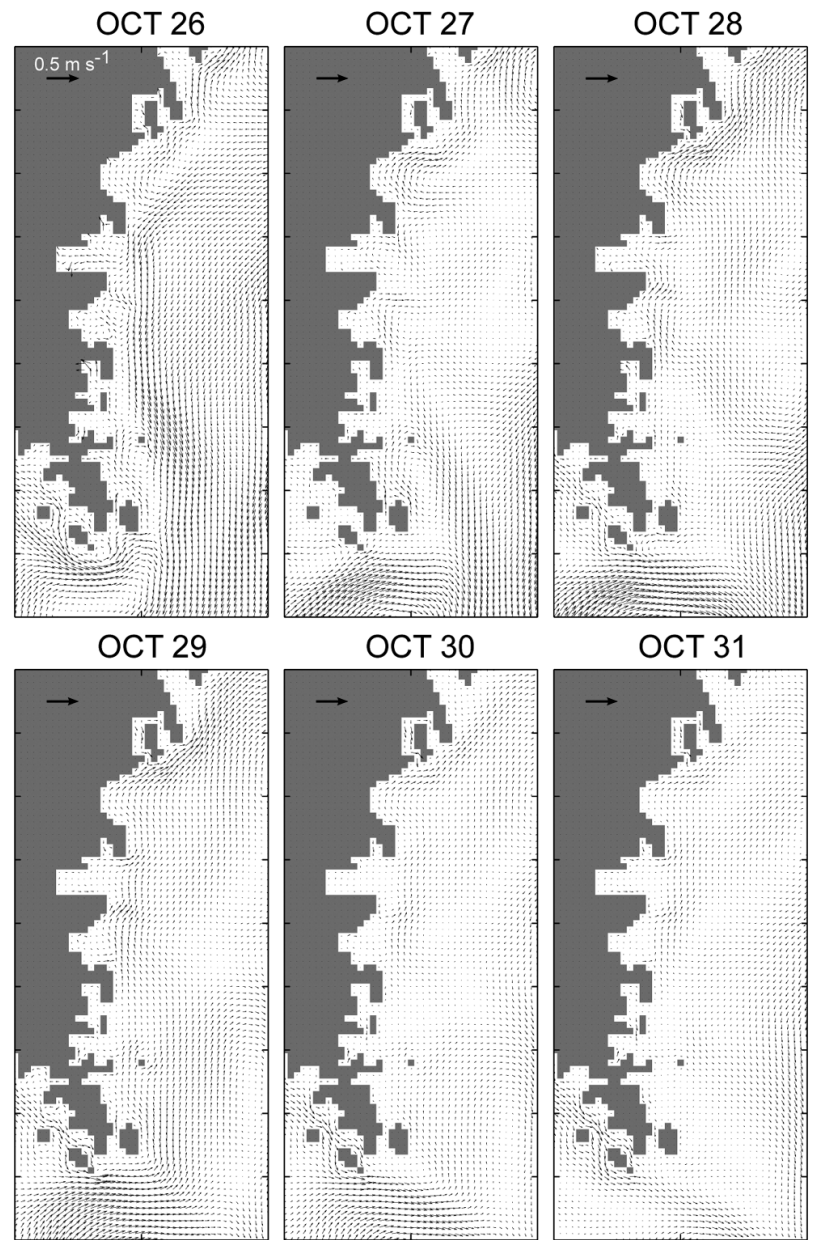

OCT 30
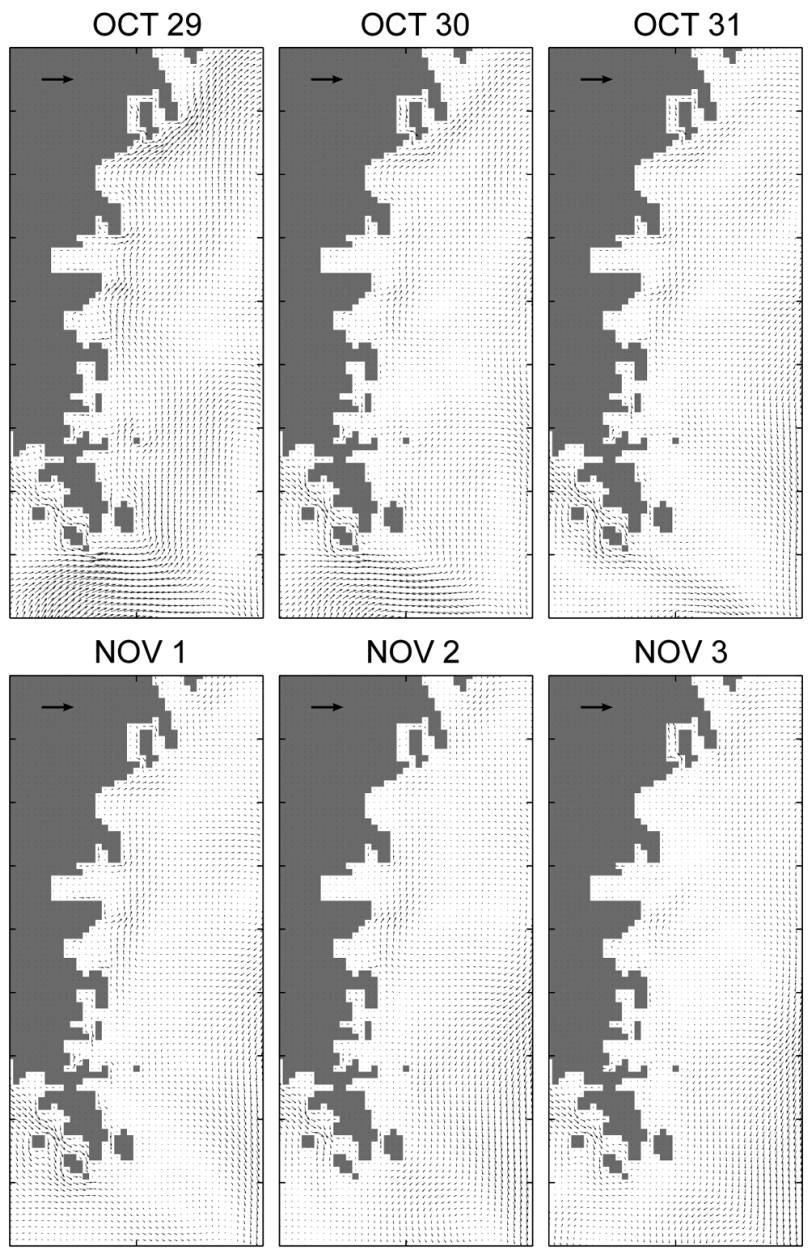

Fig. 4. Modeled hydrodynamics along the coast during the second simulation period (26 October-3 November 2006). See Fig. 3 for details

\section{Estimated settlement and spawning dates}

The SLs of newly settled abalone collected off Tomari-hama are shown in Table 1. Using the SL of 


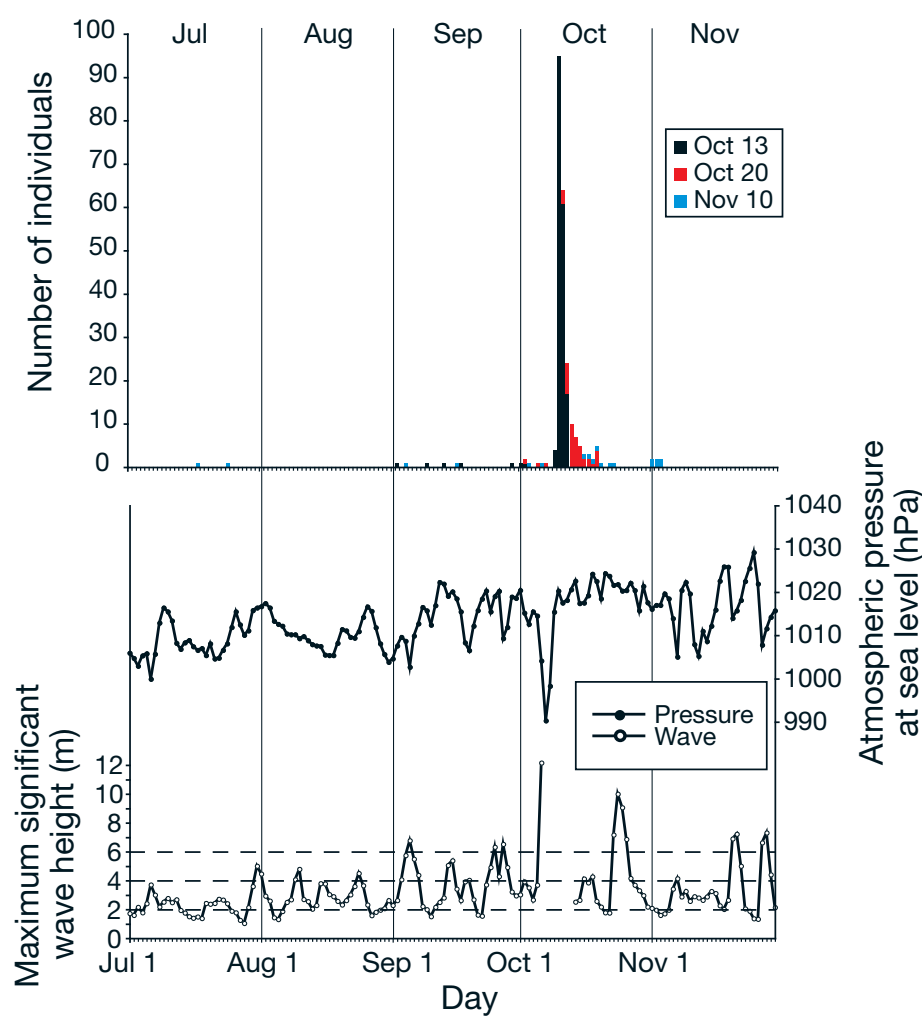

Fig. 5. Haliotis discus hannai. Estimated settlement dates of abalones and variations in atmospheric pressure at sea level and maximum significant wave heights. Bars shown in the upper panel indicate the number of individuals sampled on 13 October (black), 20 October (red) and 10 November (blue). Each bar is located at the estimated settlement date

Table 1. Haliotis discus hannai. Total number and mean shell length $(\mathrm{SL}, \pm \mathrm{SE})$ of the newly settled abalone attached to the boulders collected on each sampling date in 2006

\begin{tabular}{|lrcc|}
\hline Date & Total & SL $(\mu \mathrm{m})$ & No. of boulders \\
\hline 13 October & 184 & $387 \pm 13.9$ & 99 \\
20 October & 44 & $597 \pm 61.7$ & 101 \\
10 November & 19 & $1561 \pm 298.0$ & 92 \\
\hline
\end{tabular}

each individual, the settlement date with the highest number of individuals was estimated to be 10 October (Fig. 5), and the most settlements were estimated to have occurred between 9 and 20 October. Before this peak of settlement, a steep decrease in the atmospheric pressure at sea level and an increase in the maximum wave height were observed concurrently. From 6 to 7 October, the low-pressure system passed eastward over the Pacific coast of Honshu Island. Another peak of settlement was estimated to be between 1 and 3 November. The maximum significant wave height was over $2 \mathrm{~m}$, which is the lowest of the wave height ranges that have been reported to be associated with small-scale spawning events (see 'Estimation of settlement and spawning dates' in 'Materials and methods'), for approximately 1 wk before this peak (23 to 31 October). Strictly from Eq. (3), the spawning was estimated to have taken place between 4 and 6 October for the first peak and between 26 and 28 October for the second peak. In larval dispersal simulations, particles were released on these dates.

\section{Larval dispersal processes}

Larval dispersal processes from 7 fishery grounds were simulated for the 2 periods (4 to 12 October and 26 October to 3 November), and the results were compared on the basis of the dispersal distances (Table 2) and paths of center-ofmass (Fig. 6). In most cases (i.e. release site and simulation period), the minimum dispersal distances during the competent period were short $(<1.0 \mathrm{~km}$; Table 2). This implies that some portion of larvae could settle near the natal site. The maximum dispersal distance was 68.6 to $105.4 \mathrm{~km}$ (inclusive of all particles) and 12.6 to $60.4 \mathrm{~km}$ (inclusive of only settled particles) in the first simulation period, and 20.3 to $35.8 \mathrm{~km}$ (all particles) and 13.8 to $26.4 \mathrm{~km}$ (only settled particles) in the second period. The mean dispersal distance was in the range of 8.8 to 38.0 (all particles) and 7.2 to $23.1 \mathrm{~km}$ (only settled particles) in the first period, and 5.0 to $16.0 \mathrm{~km}$ (all particles) and 3.4 to $11.1 \mathrm{~km}$ (only settled particles) in the second period. Therefore, it is likely that larval dispersal could be greater if the settlement does not occur during the competent period (4 to $6 \mathrm{~d}$ ). Because the hydrodynamic conditions in the second period were relatively calm (discussed above), the dispersal distances in this period were generally shorter.

The paths of center-of-mass differed remarkably between the first and second simulation periods (Fig. 6). However, the positions of center-of-mass were mainly concentrated around Utatsu Saki in both periods when particles were released from UT. In addition, the positions of center-of-mass in the competent period were located near the release site (a single grid cell in this case), which was located inside the bay. In the first simulation, this topographic feature provided the retention of particles near the release site until the flow direction changed to the north. This local hydrodynamic condition caused the dispersal paths in the first simulation to be 
Table 2. Particle dispersal distance in the competent period. Minimum, maximum and mean dispersal distances were calculated for all particles (both settled and not settled) and only settled particles. OS: Oshima; OY: Ohya; UT: Utatsu; KI: Kitakami; OG: Ogatsu-tobu; YO: Yoriiso; TO: Tomari-hama

\begin{tabular}{|c|c|c|c|c|c|c|c|}
\hline \multirow{2}{*}{$\begin{array}{l}\text { Simulation } \\
\text { period }\end{array}$} & \multirow{2}{*}{$\begin{array}{l}\text { Release } \\
\text { site }\end{array}$} & \multicolumn{3}{|c|}{ All } & \multicolumn{3}{|c|}{ Only settled } \\
\hline & & $\begin{array}{c}\text { Minimum } \\
\text { distance }(\mathrm{km})\end{array}$ & $\begin{array}{c}\text { Maximum } \\
\text { distance }(\mathrm{km})\end{array}$ & $\begin{array}{c}\text { Mean } \\
\text { distance }(\mathrm{km})\end{array}$ & $\begin{array}{c}\text { Minimum } \\
\text { distance }(\mathrm{km})\end{array}$ & $\begin{array}{c}\text { Maximum } \\
\text { distance }(\mathrm{km})\end{array}$ & $\begin{array}{c}\text { Mean } \\
\text { distance }(\mathrm{km})\end{array}$ \\
\hline \multirow[t]{7}{*}{1} & OS & $<1.0$ & 94.4 & 14.3 & $<1.0$ & 60.2 & 15.3 \\
\hline & OY & $<1.0$ & 71.9 & 14.8 & $<1.0$ & 60.4 & 14.7 \\
\hline & UT & $<1.0$ & 85.2 & 8.8 & $<1.0$ & 49.1 & 7.2 \\
\hline & KI & $<1.0$ & 95.3 & 29.6 & $<1.0$ & 43.5 & 23.1 \\
\hline & OG & $<1.0$ & 105.4 & 38.0 & $<1.0$ & 30.6 & 18.8 \\
\hline & YO & $<1.0$ & 85.2 & 30.3 & $<1.0$ & 17.9 & 9.7 \\
\hline & TO & $<1.0$ & 68.6 & 26.9 & $<1.0$ & 12.6 & 9.0 \\
\hline \multirow[t]{7}{*}{2} & OS & $<1.0$ & 33.4 & 11.3 & $<1.0$ & 25.4 & 7.4 \\
\hline & OY & 2.2 & 35.8 & 16.0 & 2.2 & 25.8 & 11.1 \\
\hline & UT & $<1.0$ & 23.0 & 6.3 & $<1.0$ & 15.0 & 3.4 \\
\hline & KI & $<1.0$ & 24.9 & 6.2 & $<1.0$ & 13.8 & 4.9 \\
\hline & OG & $<1.0$ & 29.6 & 10.0 & $<1.0$ & 26.4 & 7.5 \\
\hline & YO & $<1.0$ & 26.0 & 5.8 & $<1.0$ & 16.3 & 4.4 \\
\hline & TO & $<1.0$ & 20.3 & 5.0 & $<1.0$ & 16.3 & 4.5 \\
\hline
\end{tabular}
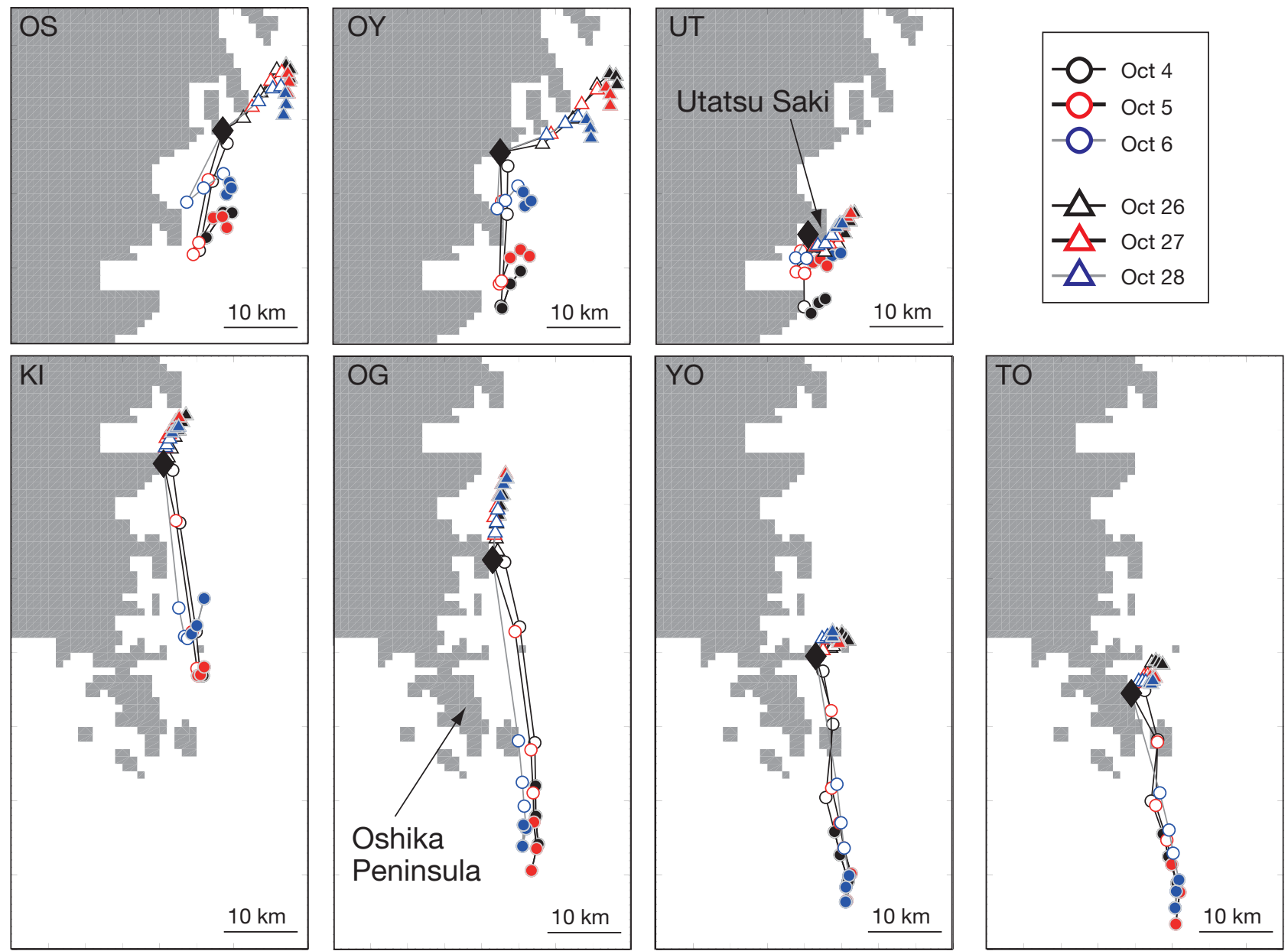

Fig. 6. Larval dispersal processes indicated by the center of mass of particles released at Oshima (OS), Ohya (OY), Utatsu (UT), Kitakami (KI), Ogatsu-tobu (OG), Yoriiso (YO) and Tomari-hama (TO). Markers show the daily positions of the center of mass after the particle release. Filled markers indicate the positions of centers-of-masses in the competent period. The positions of centers-of-masses in the first simulation period are indicated by circles whereas those in the second simulation period are indicated by triangles. The release sites are indicated by diamonds. The release dates are shown in the legend. The locations of the Utatsu Saki and the Oshika Peninsula are indicated by arrows 
Table 3. Connectivity matrices for the first (4-12 October) and second (26 October-3 November) simulation periods. The elements contain the percentage of successful particles for each site where particles were released (rows) and each site where particles settled (columns). Bold numbers indicate self-recruitment. OS: Oshima; OY: Ohya; UT: Utatsu; KI: Kitakami; OG: Ogatsu-tobu; YO: Yoriiso; TO: Tomari-hama

\begin{tabular}{|c|c|c|c|c|c|c|c|c|c|}
\hline \multirow[t]{2}{*}{ Site } & \multirow[t]{2}{*}{ OS } & \multirow[t]{2}{*}{ OY } & \multirow[t]{2}{*}{ UT } & \multirow[t]{2}{*}{$\mathrm{KI}$} & \multirow[t]{2}{*}{ OG } & \multirow[t]{2}{*}{ YO } & \multirow[t]{2}{*}{ TO } & \multicolumn{2}{|c|}{ Transport success } \\
\hline & & & & & & & & Total & $\begin{array}{c}\text { Excluding } \\
\text { self-recruitment }\end{array}$ \\
\hline \multicolumn{10}{|l|}{ First simulation period } \\
\hline OS & 32.39 & 2.23 & 7.99 & 1.44 & 0.87 & 0.04 & - & 44.96 & 12.58 \\
\hline OY & 1.16 & 2.65 & 18.71 & 7.14 & 5.00 & 0.44 & 0.07 & 35.17 & 32.52 \\
\hline UT & 0.03 & 0.14 & 17.33 & 4.76 & 4.20 & 1.91 & 0.38 & 28.75 & 11.42 \\
\hline KI & - & - & 0.97 & 15.00 & 6.04 & 2.71 & 1.15 & 25.87 & 10.87 \\
\hline OG & - & - & 0.04 & 4.22 & 3.70 & 2.78 & 0.74 & 11.48 & 7.78 \\
\hline YO & - & - & - & - & 0.20 & 4.11 & 2.05 & 6.36 & 2.26 \\
\hline TO & - & - & - & - & 0.03 & 0.73 & 0.33 & 1.10 & 0.77 \\
\hline Recruitment score (total) & 33.58 & 5.03 & 45.03 & 32.56 & 20.05 & 12.72 & 4.72 & & \\
\hline Subsidy & 1.19 & 2.37 & 27.71 & 17.56 & 16.35 & 8.61 & 4.39 & & \\
\hline \multicolumn{10}{|l|}{ Second simulation period } \\
\hline OS & 36.29 & - & - & - & - & - & - & 36.29 & 0.00 \\
\hline OY & 7.69 & 0.27 & - & - & - & - & - & 7.96 & 7.69 \\
\hline UT & 3.19 & 3.02 & 25.49 & 0.03 & - & - & - & 31.74 & 6.25 \\
\hline $\mathrm{KI}$ & - & - & 11.08 & 25.28 & 3.99 & - & - & 40.35 & 15.07 \\
\hline OG & - & - & 2.33 & 21.78 & 17.26 & 0.07 & - & 41.44 & 24.19 \\
\hline YO & - & - & - & - & 2.86 & 20.03 & 2.29 & 25.19 & 5.15 \\
\hline TO & - & - & - & - & 0.20 & 22.13 & 11.20 & 33.53 & 22.33 \\
\hline Recruitment score (total) & 47.17 & 3.29 & 38.90 & 47.09 & 24.31 & 42.24 & 13.49 & & \\
\hline Subsidy & 10.88 & 3.02 & 13.41 & 21.81 & 7.06 & 22.21 & 2.29 & & \\
\hline
\end{tabular}

similar to those in the second period, in which the weak northward flow prevailed.

The model results suggest that the larval dispersal processes in northern (OS, OY and UT) and mid- and southern coastal regions (KI, OG, YO and TO) along the coast differ (Fig. 6). Compared with the dispersal of the particles released from the northern release sites, the centers-of-mass of particles released from the mid- and southern coastal areas showed a greater dispersal along the coast towards the south in the first simulation period. Specifically, the centers-ofmass of the particles released from the southern sites (OG, YO and TO) were located in the area south of Oshika Peninsula during the competent period (4 to $6 \mathrm{~d}$ after particle release) in the first simulation (Fig. 6). In the second period, the centers-of-mass tended to be relatively near the release site during the competent period (Fig. 6). Thus, the model results indicate 2 distinct dispersal patterns for larvae from the fishery grounds on the mid- and southern coast.

\section{Population connectivity among fishery grounds}

For 4 fishery grounds (OS, UT, KI and YO), the extent of self-recruitment was greater than that of the connectivity with the other sites in both simulation periods (Table 3). These results indicate that recruitment had likely occurred at the natal sites, regardless of the timing of spawning. Among all release sites, OS and UT showed the highest and second highest self-recruitment, respectively, whereas the lowest self-recruitment occurred at OY and TO in both periods. The self-recruitment was higher in the second period at all sites except OY, compared with the first period, indicating that the calmer hydrodynamic con-

Table 4. Proportions (\%) of self-recruitment and subsidy in the recruitment score at each site in the first and second simulation periods. Total is the sum of proportions at all sites. See Table 3 for periods and sites

\begin{tabular}{|lccccc|}
\hline \multirow{2}{*}{ Site } & \multicolumn{2}{c}{$\begin{array}{c}\text { Self- } \\
\text { Secruitment }\end{array}$} & Subsidy & & \multicolumn{2}{c|}{$\begin{array}{c}\text { 2nd pelf- } \\
\text { Seliod }\end{array}$} & Subsidy \\
& recruitment & \\
\hline OS & 96 & 4 & 77 & 23 \\
OY & 53 & 47 & 8 & 92 \\
UT & 38 & 62 & 66 & 34 \\
KI & 46 & 54 & 54 & 46 \\
OG & 18 & 82 & 71 & 29 \\
YO & 32 & 68 & 47 & 53 \\
TO & 7 & 93 & 83 & 17 \\
Total & 292 & 408 & 406 & 294 \\
\hline
\end{tabular}


ditions were favorable for self-recruitment. The increase in self-recruitment was 3.90 to $8.16 \%$ at 2 sites on the northern coast (OS and UT) and 10.28 to $15.92 \%$ on the mid- (KI) and southern coast (OG, YO and TO) from the first to second period. These results indicate that mid- and southern coastal areas responded more sensitively to the change in the hydrodynamic condition in terms of self-recruitment.

The transport success was the highest when particles were released at OS (44.96\%) and OG (41.44\%) in the first and second simulation periods, respectively. This indicates the larval supply from these sites would be efficient. However, the fishery grounds TO (1.10\%) and OY (7.96\%) showed the lowest transport success in the first and second simulation periods, respectively. These results indicate that these sites were less efficient in supplying larvae to the fishery grounds. The proportion of larvae supplied from the release sites to the other sites (i.e. transport success excluding self-recruitment) can be estimated by subtracting the self-recruitment from the transport success. It was highest when particles were released from OY in the first period (32.52\%) and from OG in the second period $(24.19 \%)$, indicating that these fishery grounds were suitable as larval sources for the other sites. In contrast, the lowest values occurred at TO $(0.77 \%)$ and OS $(0 \%)$ in the first and second simulations, respectively. The scores from all northern coast sites (OS, OY and UT) decreased between the first and second simulation periods whereas that from all mid- and southern coast sites (KI, OG, YO and TO) increased. Thus, the calmer hydrodynamic conditions during the second simulation period were favorable to the release sites located on the southern coast compared with those located on the northern coast, whereas the stormy conditions in the first period were favorable to the sites located on the northern coast compared with those located on the southern coast.

Based on the recruitment, the number of connected sites varied between 3 and 7 during the first period compared with 2 to 4 sites during the second period, indicating that more release sites were connected during the stormy hydrodynamic conditions. The highest recruitment score occurred at UT (45.03\%) and OS $(47.17 \%)$ in the first and second simulation periods, respectively. These results indicate that these sites were likely to recruit more larvae than the other sites. The lowest scores occurred at TO (4.72\%) and OY $(3.29 \%)$ in the first and second periods, respectively. These 2 sites also showed the lowest transport success. The poor connectivity of these sites was partially caused by their poor self-recruitment.
The subsidy (recruitment score excluding the selfrecruitment) indicates the extent of recruitment of larvae from the other sites. This score was the highest at UT $(27.71 \%)$ and YO $(22.21 \%)$ in the first and second periods, respectively. These results indicate that these sites were suitable for receiving larvae that originated from the other sites. The subsidy was the lowest at OS $(1.19 \%)$ and TO $(2.29 \%)$ in the first and second periods, respectively. However, this score was usually lower at OY and TO in both periods. Low recruitment because of poor self-recruitment and subsidy was estimated for these sites.

The proportion of self-recruitment in the recruitment score was generally lower than that of subsidy in the first period whereas it was reversed in the second period (Table 4). It indicates that the majority of larval supply for most fishery grounds was from the other fishery grounds during the stormy conditions, but was mainly from the local source under the calmer conditions. The proportion of self-recruitment at OS was higher than that of subsidy, and the proportion of subsidy at YO was higher than that of selfrecruitment in both periods. However, there was only a slight difference $(6 \%)$ between the proportions of self-recruitment and subsidy at $\mathrm{YO}$ in the second period. In contrast, the northernmost fishery ground OS was strongly self-maintained under both hydrodynamic conditions.

\section{DISCUSSION}

Haliotis discus hannai has the ability to spawn multiple times in a single spawning season (Fukazawa et al. 2005, 2007), and their larvae and postlarvae appear several times during the season in the natural environment (Sasaki \& Shepherd 1995, Takami et al. 2006, 2008). From the model results, the larval dispersal processes of $H$. discus hannai on the Miyagi coast were expected to differ depending on the prevailing hydrodynamic conditions at the timing of spawning and the locations of natal fishery grounds. Larval dispersal was estimated to be greater in the stormy hydrodynamic conditions than in the calmer conditions. The lowpressure system moved northeastward along the Pacific coast of Honshu Island during the first simulation period, causing the shift of wind from strong southwestward to weaker northeastward in the study area. Low-pressure systems that form and develop over the northwestern Pacific Ocean travel northeastward off the Pacific coast of Japan (Yoshida \& Asuma 2004). The low-pressure system 
that caused the stormy conditions in the first simulation period followed a path similar to the standard route of typhoons in September, which is the peak of the spawning season in this area (Sasaki 2001). Thus, the pattern of long-distance larval dispersal simulated in this study can be expected to occur during the spawning seasons. However, the larval dispersal was simulated for 2 distinct hydrodynamic conditions in a single year, and both long- and short-distance dispersal can vary depending on weather and hydrodynamic conditions. Although the present study has shown the larval dispersal patterns and distances off the Miyagi coast, their variations should be investigated in future studies.

In the first simulation period, particles from the fishery grounds located in the mid- and southern parts of the coast widely dispersed southward whereas the extent of larval dispersal was shorter in the second period. These results indicate that abalone in the fishery grounds on the mid- and southern coast exhibit 2 different dispersal processes that have been previously suggested from larval distributions off Oshima Island (OS in the present study) (Sasaki \& Shepherd 1995). Similar to the dual larval dispersal patterns in our simulations, the larvae of the coral Seriatopora hystrix in northern Western Australia are recruited locally but occasionally disperse over long distances (Underwood et al. 2007). The other 3 large abalone species in Japan appear to have 2 larval dispersal patterns (Miyake et al. 2009). Therefore, large abalone species in Japan are likely to exhibit dual dispersal patterns for the recruitment at local and remote sites. However, the occurrence of these 2 dispersal patterns may depend on the local hydrodynamic features around the natal site because the dispersal patterns did not seem to differ for the fishery grounds located in the northern part of the model region off the Sanriku coast. Both of these dispersal patterns are important in terms of adaptation (Sasaki \& Shepherd 1995). Short-distance dispersal can result in local adaptability (Strathmann 1986), but may cause vulnerability to fluctuations in local environmental conditions (Kinlan \& Gaines 2003). In contrast, long-distance dispersal is advantageous for genetic variability (Strathmann 1986) and homogeneous recovery following large disturbances (Reed et al. 2000), but disadvantageous because of accumulation of deleterious recessive genes (Strathmann 1986). The number of newly settled abalone after the stormy conditions was estimated to be much greater than that after the calmer conditions, implying the higher availability of larvae after the passage of the low-pressure system. However, the model results suggested that recruitment was poorer in the stormy conditions. It is possible that the subpopulations are maintained by short-distance dispersal, which provides a higher chance of self-recruitment; however, higher availability of larvae may compensate for a low chance of recruitment because of the largerscale dispersal. In contrast to the large species, the spawning of the small species Haliotis diversicolor is triggered only by the passage of typhoons and the associated events (Onitsuka et al. 2007). Although there are no studies on their larval dispersal, it is likely that $H$. diversicolor only exhibit a broad larval dispersal pattern. The larval dispersal pattern of the small species may differ from the patterns of the large species because of their local environment, in which typhoons pass frequently during their spawning season, and the subsequent storm can be a reliable spawning cue (Onitsuka et al. 2007).

The model results indicate that larval dispersal could occur at distances in the range of $<1 \mathrm{~km}$ to $>100 \mathrm{~km}$, but the dispersal distances were short when the larvae settled within the competent period. The dispersal distance differed temporally and spatially; however, sheltered locations such as UT may exhibit relatively invariable larval dispersal processes. The hydrodynamic conditions in the first period were stormy, and this could cause the larvae originated from the southern part of the Oshika Peninsula to reach deeper areas south of the peninsula during the competent period. In a controlled environment, the larvae of Haliotis discus hannai can extend their larval period (Takami et al. 2002). If the larvae were not able to extend their larval period in the natural environment, most larvae from the southern fishery grounds would not survive. The connectivity simulation results suggest that the contribution to the metapopulation on the coast by the subpopulations in the southern fishery grounds would be less under the stormy conditions. In the calmer hydrodynamic conditions, most subpopulations tended to supply larvae locally and to their northern neighboring subpopulations because of the weak northward flow. The subpopulations in the northern and midfishery grounds would be more important in maintaining the metapopulation in case of frequent spawning events occurring concurrently with passages of low-pressure systems. In such cases, the metapopulation in this area could be classified as a directional metapopulation (Lipcius et al. 2008), and restocking in the downstream subpopulations would not enhance the upstream subpopulations.

The self-recruitment in OS was the highest during both simulation periods. Most parts of this fishery 
ground are sheltered from the influence of stronger currents offshore, and this topographic feature appears to have resulted in high self-recruitment. The self-recruitment in UT was the second highest in both simulation periods. The center-of-mass of particles released at this site was located close to the natal site during the competent period, and the mean dispersal distances of settled particles were the shortest among the particle release sites in both periods. Although only 2 cases were simulated in this study, sheltered fishery grounds such as OS and UT tend to retain larvae and are potentially suitable to establish harvest refugia if the aim is to locally replenish the subpopulation. Furthermore, UT had a high recruitment score and subsidy. This implies that larval supply could be expected from the natal and other fishery grounds, and it is suitable in terms of recruitment and establishment of a harvest refugium when compared with other sites on the scale of fishery grounds.

The larval dispersal simulations under the 2 types of hydrodynamic conditions indicate that more than half of the fishery grounds in the present study had higher self-recruitment than connectivity with the other fishery grounds. This implies that these fishery grounds were more effective in self-replenishment. However, poor self-recruitment could occur, and thus the restocking and protection of local resources in a fishery ground does not always lead to an increase in the local recruitment. The extent of self-recruitment changed spatially and temporally. It was estimated that the self-recruitment could decrease in the case of stormy hydrodynamic conditions, and some small fishery grounds (OY and TO) had lower selfrecruitment in both stormy and relatively calm hydrodynamic conditions. The proportion of selfrecruitment against that of subsidy was evidently lower at the majority of fishery grounds in the stormy conditions. Thus, the connectivity with the other subpopulations could be important depending on the frequent hydrodynamic conditions at the spawning in the area. The larval supply from non-local larval sources to UT and YO was estimated to be higher than the other fishery grounds in the stormy and calmer hydrodynamic conditions, respectively. The establishment of protected areas in the fishery grounds with high subsidy may be effective in terms of recruitment even if the local adult population is not replenished artificially. Although 2 main spawning events of the season were simulated, the suitability of a site should be carefully considered, as this was evaluated on the basis of larval dispersal during 2 periods in the present study, and could change if spawning events in either stormy or calm hydro- dynamic conditions occur more frequently. For the northern fishery grounds such as OY, their suitability may be underestimated because these sites could recruit/supply larvae from/to the fishery grounds located north of the model region, which were not incorporated in the present study. Habitat quality in the destination of larvae can influence the efficacy of restocking in the source subpopulations (Lipcius et al. 2008). Food sources in the potential larval settlement areas should be taken into account because they can be limiting factors for postlarval survival (Kawamura et al. 1998, Sasaki \& Shepherd 2001).

Mortality and vertical behaviors were not incorporated into the model. Mortality cannot be clarified because of the difficulty in tracking the larvae in the field, and thus the model was simplified. The vertical behavior of larvae could influence the larval dispersal, especially the dispersal distance. Our study species inhabit rocky shores and spawn concurrently with stormy ocean conditions or when wave heights are relatively greater. Based on the ecology of this species, it is likely that those larvae experience the turbulent mixing of the water for a few days after spawning, and the strong mixing could overwhelm their vertical swimming or sinking behavior. In the simulations, the particles were immediately stopped (i.e. settled) when they were transported to the nearshore areas. For these reasons, the assumptions employed in the present study were considered reasonable.

In the present study, larval dispersal processes and connectivity in a single year were investigated. Therefore, it may be necessary to determine interannual variation in the larval dispersal processes, connectivity among fishery grounds and suitable locations for harvest refugia. Because the results could be complicated by other factors, such as the abundance of adult abalone in each fishery ground, connectivity and other related values were calculated on the assumption that the amount of larvae originating from each fishery ground was equal. The present study has shown that larval dispersal processes can vary within the scale of the coast (ca. $80 \mathrm{~km}$ ), depending on the location of the larval source. For management purposes, this variance implies that it is necessary to investigate the larval dispersal processes from each larval source, even when they are located closely together on the same coast.

Acknowledgements. We thank Drs. H. Nakata, T. Otake and T. Yamakawa for helpful suggestions. We appreciate valuable comments from Dr. Lipcius and two anonymous reviewers during the revision of this paper. 


\section{LITERATURE CITED}

Allison GW, Lubchenco J, Carr MH (1998) Marine reserves are necessary but not sufficient for marine conservation. Ecol Appl 8:S79-S92

Babcock RC, Kelly S, Shears NT, Walker JW, Willis TJ (1999) Changes in community structure in temperate marine reserves. Mar Ecol Prog Ser 189:125-134

Cowen RK, Sponaugle S (2009) Larval dispersal and marine population connectivity. Annu Rev Mar Sci 1:443-466

Cudney-Bueno R, Lavín MF, Marinone SG, Raimondi PT, Shaw WW (2009) Rapid effects of marine researves via larval dispersal. PLoS ONE 4:e4140

Delft Hydraulics (2007) Delft3D-PART user manual version 2.13. WLIDelft Hydraulics, Delft

Delft Hydraulics (2008) Delft3D-FLOW user manual version 3.14. Deltares, Delft

- Dufour V, Jouvenel JY, Galzin R (1995) Study of a Mediterranean reef fish assemblage: comparisons of population distributions between depths in protected and unprotected areas over one decade. Aquat Living Resour 8: $17-25$

> Durán LR, Castilla JC (1989) Variation and persistence of the middle rocky intertidal community of central Chile, with and without human harvesting. Mar Biol 103:555-562

Fukazawa H, Takami H, Kawamura T, Watanabe Y (2005) The effect of egg quality on larval period and postlarval survival of an abalone Haliotis discus hannai. J Shellfish Res 24:1141-1147

Fukazawa H, Kawamura T, Takami H, Watanabe Y (2007) Oogenesis and relevant changes in egg quality of abalone Haliotis discus hannai during a single spawning season. Aquaculture 270:265-275

Hanawa K, Mitsudera H (1987) Variation of water system distribution in the Sanriku coastal area. J Oceanogr Soc Jpn 42:435-446

Hayashi I (1983) Larval shell morphology of some Japanese Haliotids for the identification of their veliger larvae and early juveniles. Venus 42:49-58 (in Japanese with English abstract)

Hinata H, Furukawa K (2006) Ecological network linked by the planktonic larvae of the clam Ruditapes philippinarum in Tokyo Bay. In: Wolanski E (ed) The environment in Asia Pacific harbours. Springer, Dordrecht

Kawamura T, Roberts RD, Takami H (1998) A review of the feeding and growth of postlarval abalone. J Shellfish Res 17:615-625

Kawamura T, Takami H, Saido T (2002) Early life ecology of abalone Haliotis discus hannai in relation to recruitment fluctuations. Fish Sci 68(Suppl. 1):230-233

Kelly S, Scott D, MacDiarmid AB, Babcock RC (2000) Spiny lobster, Jasus edwardsii, recovery in New Zealand marine reserves. Biol Conserv 92:359-369

Kinlan BP, Gaines SD (2003) Propagule dispersal in marine and terrestrial environments: a community perspective. Ecology 84:2007-2020

Lipcius RN, Stockhausen WT, Eggleston DB (2001) Marine reserves for Caribbean spiny lobster: empirical evaluation and theoretical metapopulation recruitment dynamics. Mar Freshw Res 52:1589-1598

> Lipcius RN, Eggleston DB, Schreiber SJ, Seitz RD and others (2008) Importance of metapopulation connectivity to restocking and restoration of marine species. Rev Fish Sci 16:101-110

Matsumoto K, Takanezawa T, Ooe M (2000) Ocean tide models developed by assimilating TOPEX/POSEIDON altimeter data into hydrodynamical model: a global model and a regional model around Japan. J Oceanogr 56:567-581

> McShane PE, Black KP, Smith MG (1988) Recruitment processes in Haliotis rubra (Mollusca: Gastropoda) and regional hydrodynamics in southeastern Australia imply localized dispersal of larvae. J Exp Mar Biol Ecol 124: 175-203

> Miyake Y, Kimura S, Kawamura T, Horii T, Kurogi H, Kitagawa T (2009) Simulating larval dispersal processes for abalone using a coupled particle-tracking and hydrodynamic model: implications for refugium design. Mar Ecol Prog Ser 387:205-222

> Miyake Y, Kimura S, Kawamura T, Kitagawa T, Hara M, Hoshikawa H (2010) Estimating larval supply of Ezo abalone Haliotis discus hannai in a small bay using a coupled particle-tracking and hydrodynamic model: insights into the establishment of harvest refugia. Fish Sci 76:561-570

Miyazawa Y, Zhang RC, Guo XY, Tamura H and others (2009) Water mass variability in the western North Pacific detected in a 15-year eddy resolving ocean reanalysis. J Oceanogr 65:737-756

> North EW, Schlag Z, Hood RR, Li M, Zhong L, Gross T, Kennedy VS (2008) Vertical swimming behavior influences the dispersal of simulated oyster larvae in a coupled particle-tracking and hydrodynamic model of Chesapeake Bay. Mar Ecol Prog Ser 359:99-115

Onitsuka T, Kawamura T, Horii T, Takiguchi N, Takami H, Watanabe Y (2007) Synchronized spawning of abalone Haliotis diversicolor triggered by typhoon events in Sagami Bay, Japan. Mar Ecol Prog Ser 351:129-138

Piggott MP, Banks SC, Tung P, Beheregaray LB (2008) Genetic evidence for different scales of connectivity in a marine mollusc. Mar Ecol Prog Ser 365:127-136

Reed DC, Raimondi PT, Carr MH, Goldwasser L (2000) The role of dispersal and disturbance in determining spatial heterogeneity in sedentary organisms. Ecology 81: 2011-2026

Russ GR, Alcala AC (2003) Marine reserves: rates and patterns of recovery and decline of predatory fish, 1983-2000. Ecol Appl 13:1553-1565

Saijo Y, Ichimura S (1960) Primary production in the Northwestern Pacific Ocean. J Oceanogr Soc Jpn 16:139-145

Sasaki R (2001) Ecological studies on the recruitment structure in abalone Haliotis discus hannai INO. Miyagi Pref Rep Fish Sci 1:1-86 (in Japanese with English abstract)

Sasaki R (2005) Abalone. In: Mori K (ed) Aquaculture System, Vol. 3: Molluscs, crustaceans, sea urchins and algae. Koseisha Koseikaku, Tokyo (in Japanese)

> Sasaki R, Shepherd SA (1995) Larval dispersal and recruitment of Haliotis discus hannai and Tegula spp. on Miyagi coasts, Japan. Mar Freshw Res 46:519-529

Sasaki R, Shepherd SA (2001) Ecology and post-settlement survival of the Ezo abalone, Haliotis discus hannai, on Miyagi Coasts, Japan. J Shellfish Res 20:619-626

Statistics Department, Tohoku Regional Agricultural Administration Office (2008) Annual report of the 54th agriculture, forestry and fisheries statistics of Miyagi Prefecture. Association of Agriculture and Forestry Statistics in Miyagi, Sendai (in Japanese)

Stephens SA, Broekhuizen N, Macdiarmid AB, Lundquist CJ, McLeod L, Haskew R (2006) Modelling transport of 
larval New Zealand abalone (Haliotis iris) along an open coast. Mar Freshw Res 57:519-532

Strathmann RR (1986) What controls the type of larval development? Summary statement for the evolution session. Bull Mar Sci 39:616-622

Takami H, Kawamura T, Yamashita Y (2002) Effects of delayed metamorphosis on larval competence, and postlarval survival and growth of abalone Haliotis discus hannai. Aquaculture 213:311-322

Takami H, Oshino A, Sasaki R, Fukazawa H, Kawamura T (2006) Age determination and estimation of larval period in field caught abalone (Haliotis discus hannai Ino 1953) larvae and newly metamorphosed post-larvae by counts of radular teeth rows. J Exp Mar Biol Ecol 328: 289-301

Takami H, Saido T, Endo T, Noro T, Musashi T, Kawamura T (2008) Overwinter mortality of young-of-the-year Ezo

Editorial responsibility: Romuald Lipcius,

Gloucester Point, Virginia, USA abalone in relation to seawater temperature on the North Pacific coast of Japan. Mar Ecol Prog Ser 367:203-212

- Underwood JN, Smith LD, Oppen MJHV, Gilmour JP (2007) Multiple scales of genetic connectivity in a brooding coral on isolated reefs following catastrophic bleaching. Mol Ecol 16:771-784

> Warner JC, Geyer WR, Lerczak JA (2005) Numerical modeling of an estuary: a comprehensive skill assessment. J Geophys Res 110:C05001

$>$ Watson JR, Mitarai S, Siegel DA, Caselle JE, Dong C, McWilliams JC (2010) Realized and potential larval connectivity in the Southern California Bight. Mar Ecol Prog Ser 401:31-48

Yoshida A, Asuma Y (2004) Structures and environment of explosively developing extratropical cyclones in the northwestern Pacific region. Mon Weather Rev 132: 1121-1142

Submitted: September 23, 2010; Accepted: August 12, 2011 Proofs received from author(s): October 21, 2011 